\title{
Pendampingan Kelompok Mahasiswa dalam Memanfaatkan Marketplace dan Online Shop Sebagai Media Pemasaran Produk Inovasi Pesantren
}

Sudriyanto ${ }^{1}$, Isti Ghulam Hidayatullah ${ }^{2}$, M. Alman David ${ }^{3}$, Putri Tsamrotul Fu'adiyah $^{4}$, M. Fajar Santoso ${ }^{5}$, M. Lukman Hakim ${ }^{6}$

Universitas Nurul Jadid, Probolinggo 1,2,3,4,5,6

\{sudriyanto@unuja.ac.id ${ }^{1}$, hiday.isti@gmail.com², malmandifaz@gmail.com³, ptsamrotulfuadiah@gmail.com ${ }^{4}$,mfajarsantoso266@gmail.com ${ }^{5}$,

hakimlukman5128@gmail.com6\}

Submission: 2021-03-27 Received: 2021-04-29 Published: 2021-04-30

\section{Keywords:}

Training, Online

Marketing, Public

Service,

Marketplace.
Katakunci:

Pelatihan, Online Marketing, Pelayanan publik, Marketplace.

\begin{abstract}
Based on the results of a survey report from the Indonesian Internet Service Providers Association (AP JII) on June 225,2020 , the total number of Indonesian internet users is 73.7 percent or 196,714,070.3 million people from the total population in Indonesia of 266,911,900 people. . Fenomina is currently using the internet as an increasing use of the internet which is being used by businesses as a media for online marketing promotion. Many companies have implemented online sales so much that it has had an impact on the decline in the turnover of other companies that are still offline. The purpose of this activity is to improve the skills and knowledge of companies and students so that they can implement marketplace-based online sales. The essence of the online marketing assistance activity for one full month involving 20 HIMATIKA students as participants. From this mentoring activity, the team received a very enthusiastic and satisfying welcome from the NJ Mart and the Informatics Engineering Student Association (HIMATIKA) UNUJA Faculty of Engineering as partners during the training and mentoring activities. From the overall results from the beginning of the implementation to the end of the mentoring, it shows positive results and becomes a business opportunity and can increase student interest in entrepreneurship.
\end{abstract}


meningkatkan keterampilan dan pengetahuan perusahaan dan mahasiswa agar bisa menerapkan penjualan secara online berbasis marketplace. Inti dari kegitan pendampingan pemasaran secara online selama satu bulan penuh dengan melibatkan kelompok HIMATIKA sejumlah 20 mahasiswa sebagai peserta. Dari kegiatan pendampingan ini tim mendapatkan sambutan yang begitu antusias baik dari pihak NJ Mart dan kelompok Himpunan Mahasiswa Teknik Informatika (HIMATIKA) Fakultas Teknik UNUJA sebagai mitra pada saat pelaksanaan kegiatan pendampingan berlangsung. Hasil dari keseluruhan dari awal sampai akhir pelaksanaan pendampingan menunjukkan hasil yang positif dan menjadi peluang usaha serta dapat meningkatkan minat mahasiswa untuk berwirausaha.

\section{Pendahuluan}

Berdasarkan hasil laporan survey dari Asosiasi Penyelenggara Jasa Internet Indonesia (AP JII) pada 2 - 25 Juni 2020, jumlah total pengguna internet Indonesia sebanyak 73,7 persen atau 196.714.070,3 juta orang dari jumlah total penduduk di Indonesia sebanyak 266.911 .900 orang seperti grafik pada gambar 1 sebagai berikut.

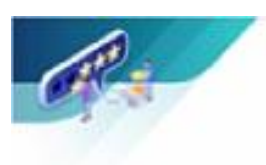

\section{Penetrasi dan Pengguna Internet
2019-2020(Q2)}

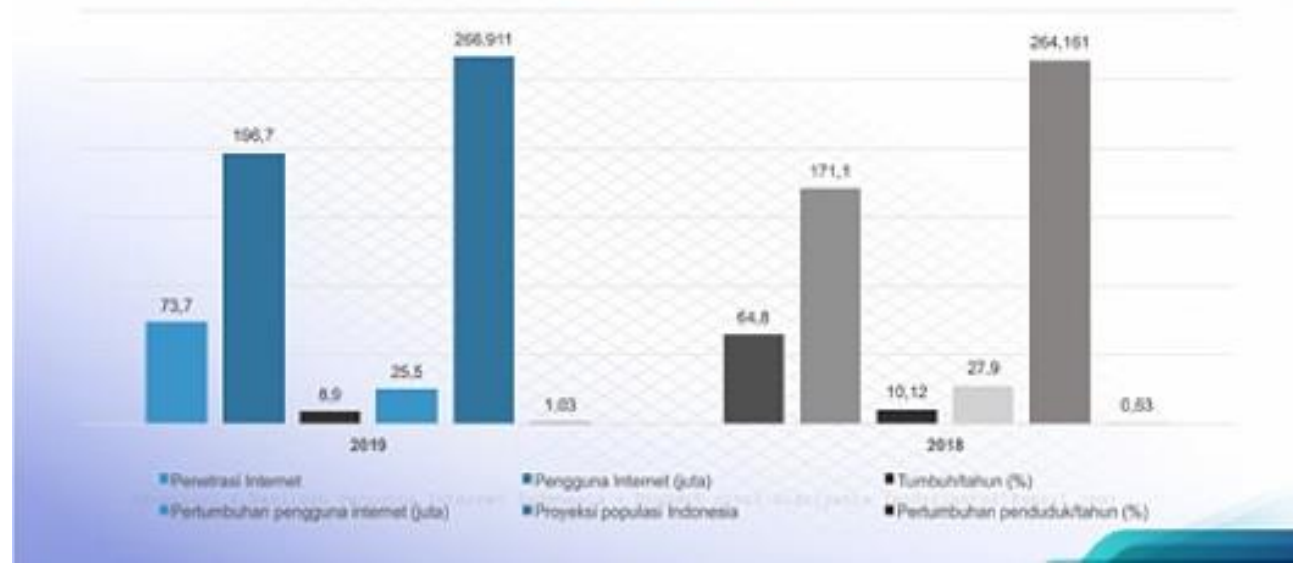

Sumber: (Aditya , Aan , Dwi, Reagan , \& dkk, 2020) APJII, 2020

Gambar 1. Jumlah Pengguna Internet dan popupalis penduduk di Indonesia 
Fenomina pada saat ini begitu meningkatnya penggunaan internet yang di manfaatkan oleh pelaku bisnis sebagai media promosi online marketing. Terdapat beberapa jenis online marketing yang memanfaatkan layanan media internet. Kotler dan Amstrong dalam bukunya (Kotler \& Gary , 2009), pada saat ini dimana banyaknya perusahaan yang mulai beralih ke online marketing melalui sosial media, merancang website marketing, menempelkan iklan ataupun promo secara online, dan memanfaatkan email pemasaran atau spam. Perusahaan yang keuangannya memadai ditambah dengan angaran biaya pemasaran yang memadai, bisa menngunakan bermacam jenis layanan pemasaran online tersebut. Namun untuk perusahaan yang aggarannya sangat minim bisa memanfaatkan layanan online marketing yang tidak dikenakan biaya seperti sosial media diantaranya seperti Facebook, Instagram, dan marketplace.

Dampak online shop sudah mulai berefek pada terjadinya pola perubahan konsumsi masyarakat kita kususnya konsumsi elektronik, pakaian, yang biasa belanja offline di gerai, toko, butik, mal atau supermarket sebagian customer beralih berbelanja online. Para pelaku bisnis pada saat ini yang hanya bisa memanfaatkan pemasaran secara offline atau konvensional sangat berpotensi terimbas dampak yaitu merosotnya omset penjualan. Adanya beberapa supermarket yang ada di tanah air menutup gerai dampak menurunnya daya beli masyarakat secara offline dengan menurunnya omset perusahaan.

Merespon Fenomina-fenomina yang terjadi pada saat ini, para pelaku bisnis perlu secepatnya beradaptasi dengan semakin pesatnya perkembangan serta kemajuan tektologi informasi dan bisa menyesuaikan dengan berubahnya perilaku masyarakat kita dalam berbelanja, yaitu dengan beralihnya dari pemesaran konvensional atau offline ke online ataupun kombinasin online offline. Apabila suatu perusahaan tidak bisa beradaptasi dengan sesegera mungkin, maka akan ketinggalan oleh kompetitor yang sistem pemasarannya sudah online serta sangat berpotensi beralihnya customer ke cara belanja yang lebih efektif dan efisien yaitu online.

Sebagai respon pada fenomena tersebut, sesuai dengan Visi UNUJA yang memiliki basis tata kelola unggul dalam pengembangan ilmu pengetahuan, teknologi dan berjiwa kewirausahaan dan berwawasan keindonesiaan. Program Studi Teknik Informatika Fakultas Teknik Universitas Nurul Jadid 
Paiton Probolinggo (Sekretariat, 2021), menggelar kegiatan pengabdian masyarakat bagi kelompok mahasiswa Himatika Universitas Nurul Jadid. Sebagai pilot project, terpilih mahasiswa yang berdomisili di Pondok Pesantren Nurul Jadid (Mahasiswa yang berstatus santri), yang akan di proyeksi untuk memasarkan produk-produk hasil kreatifitas pondok pesantren Nurul Jadid, berdasarkan hasil wawancara dengan pengelola NJ Mart selaku unit usaha yang memasarkan produk-produk yang dihasilkan oleh pondok pesantren itu sendiri masih konvensional, dimana omset penjualnnya kurang maksimal mengingat sebagian customer beralih dari belanja offline ke online yang marak di kalangan milenial pada saat ini.

Pada kegiatan pengabdian ini yang pertama bertujan untuk mendorong perusahhan mitra dan mahasiswa yang berstatus santri yang pada saai ini menggunakan media pemasaran secara offline untuk beralih dengan memanfaatkan pemasaran menggunakan media online sehingga bisa meningkatkan omset serta mempertahankan customer; yang kedua, sebagai syarat tridarma institusi perguruan tinggi yaitu mengaplikasikan, mengembangkan, menstransformasiksn dan mentransfer ilmu pengetahuan, teknologi serta seni kepada warga masyasrakat luas kususnya disekitar kampus dan mahasiswa yang berstatus santri.

Adapun manfaat yang didapat pada aktivitas pengabdian ini, yang pertama untuk perusahaan mitra dan mahasiswa kususnya, yaitu mengembangkan SDM (sumber daya manusia) dalam pengetahuan dan keterampilan pemasaran secara online dengan marketplace; yang kedua, mempunyai akun pemasaran online denagn marketplace yang bisa digunakan pemasaran secara online; yang ketiga, untuk dosen dan mahasiswa, yaitu memperoleh data-data dan informasi ter update dalam implementasi ilmu pengetahuan dan teknologi di kalangan masyarakat untuk pengenbangan ilmu pengetahuan dalam rangka pengkajian ilmiah.

Berdasarkan potensi di atas, tim pengusul termotivasi dan tergerak untuk melakukan Pendampingan kepada Kelompok Mahasiswa dalam Memanfaatkan Marketplace dan Online Shop Sebagai Media Pemasaran Produk Inovasi Pesantren. 


\section{Metode}

Metode Pelatihan yang dilaksanakan adalah bekerjasama dengan NJ Mart selaku unit uasaha Podok Pesantren Nurul Jadid dan kelompok Himpunan Mahasiswa Informatika (HIMATIKA) Fakultas Teknik Universitas Nurul Jadid serta mencari dan menganalisis permasalahan yang ada sehingga bisa memberikan terobosan dan solusi yang tepat dan efektif untuk memberi motivasi sebagai pebisnis di kalangan mahasiswa Universitas Nurul Jadid Paiton Probolinggo. Berikut tahapan-tahapan pelaksanaan pengabdian masyarakat bisa dilihat pada gambar 3 sebagai berikut :

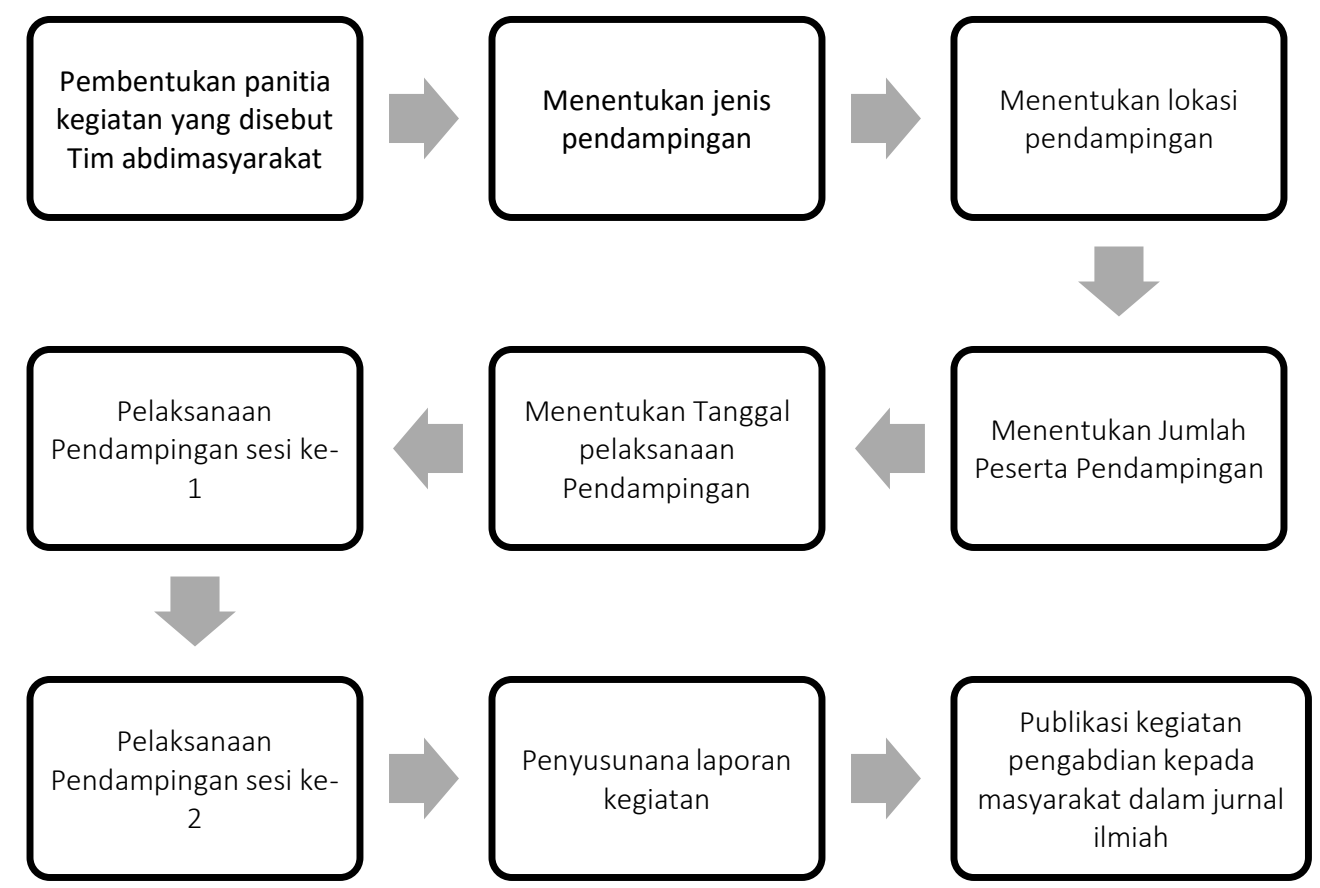

Gambar 3. Alur Tahap Pelaksanaan Pengabdian kepada Masyarakat

Dari kesembilan tahapan tersebut di atas untuk penjelasan detailnya sebagai berikut dibawah ini:

1. Membentuk panitia kegiatan yang disebut tim abdimasayarakat yang terdiri dari 7 anggota yang mana terdiri dari satu orang dosen prodi 
Teknik Informatika yang berperan sebagai tutor, konseptor, dan fasilitator.

2. Tim Abdimasyarakat menetukan jenis pendmpingan pada kelompok himpunan Mahasiswa Teknik Informatika (HIMATIKA) dalam memanfaatkan Marketplace dan online shop sebagai media pemesaran produk inovasi pesantren.

3. Menentukan lokasi pendampingan, dimana dalam rapat disepakati bersama lokasi pelatihan dan pendampingan di laboratorium Komputer Fakultas Teknik Universitas nurul Jadid.

4. Tim menentukan jumlah peserta pelatihan dan pendampingan, diantaranya dipilih 20 mahasiswa aktif yang tergabung dalam Kelompok Himpunan Mahasiswa Teknik Informatika (HIMATIKA) Fakultas Teknik Universitas Nurul Jadid sebagai Pilot Project.

5. Tim menentukan tangal pelaksanaan pelatihan dan pendampingan kepada kelompok mahasiswa HIMATIKA Fakultas Teknik Universitas Nurul Jadid dimana hasil rapat disepakati dan dilaksanakan pada tanggal 4- 31 Maret 2021.

6. Pelaksanaan pendampingan pada sesi ke-1 pada tanggal 4 Maret 2021 dengan menerapkan protokol kesehatan, berikut jadwal kegitan pelatihan dan pendampingannya :

a. Tanggal 4 Maret 2021, Jam 09.30 - 12.00, dengan materi Pengenalan Marketplace dan Online Shop sebagai media pemasaran prodak inovasi Psantren.

b. Tanggal 4 Maret 2021, Jam $13.00-16.00$, dilanjutkan dengan materi pembuatan email dan akun marketplace yang dipraktekkan langsung oleh mahasiswa.

7. Pelaksanaan pendampingan pada sesi ke-2 pada tanggal 5 - 31 maret 2021 dilakukan pendampingan selama satu bulan penuh oleh Tim baik dari kejauhan secara online maupun tatap muka langsung dengan tetap menerapkan protokol kesehatan.

8. Penyusunan laporan kegiatan yang di akhiri dengan membuat dan menyusun laporan kegiatan dan disampaikan kepada pimpinan Univesitas sebagai wujud akuntabilitas serta pemenuhan salah satu tugas kewajiban tridarma perguruan tinggi.

9. Publikasi kegiatan pengabdian kepada masyarakat dalam jurnal ilmiah dengan menggunakan pendekatan ilmiah, dimana publikasi dijurnal 
ilmiah diharapkan bisa memperbanyak rrferensi ilmiah yang terkait dengan pelaksanaan pengabdian kepada masyarakat.

\section{Hasil dan Pembahasan}

Secara keseluruhan pada hasil pelatihan serta pembimbingan pada kegiatan pengabdian kepada masyarakat yang mana ada empat tahapan, yang pertama pra kegiatan, yang kedua pelatihan, yang ketiga pendampingan, serta dan yang keempat pasca kegiatan. Dari keempat tahapan tersebut beserta uraian-uraian kegiatan bisa dilihat pada gambar 4 . Tahapan yang pertama, pra kegiatan, yang meliputi :

1. Membentuk panitia dalam kegiatan yang disebut Tim Abdimasyarakat yang terdiri dari tujuh anggota, dimana satu orang dosen program studi Teknik Informatika, Fakultas Teknik Universitas Nurul Jadid dimana satu orang dosen mempunyai perang sebagai tutor, konseptor dan fasilitator.

2. Tim Abdimasyarakat menyusun dan membuat proposal pada kegiatan yang diajukan pada pimpinan Universitas Nurul Jadid dan NJ Mart selaku unit usaha pesantren dan kelompok mahasiswa Himpunan Mahasiswa Teknik Informatika (HIMATIKA) Fakultas Teknik Universitas Nurul Jadid sebagai calon mitra.

3. Tinjauan pustaka yang berkaitan erat dengan pelatihan online markrting, dan marketplace. Tinjauan ini dilakukan untuk menemukan data-data empiris dan konsep teori sebagai acuan dalam penyusunan modul pelatihan online marketing, slide materi pelatihan, dan buku panduan dalam proses pendampingan kepada peserta pelatihan dan pendampingan.

4. Kunjungan serta survey langsung sekaligus observasi ke NJ Mart selaku perusahaan mitra dan kelompok himpunan Mahasiswa Teknik Informatika Fakultas Teknik Universitas Nurul Jadid untuk sosialisai terkait kegiatan pelatihan dan pendampingan.

5. Melakukan proses pengurusan perizinan terkait tempat pelatihan dan pendampingan, dan pendataan serta pendaftaran peserta pendampingan, setelah mendapatkan data perusahaan mitra, mahasiswa, lokasinya, dan waktu pendampingannya. 
6. Tim Abdimasyarakat membuat dan menyusun modul dengan tema online business dan online marketing berbasis marketplace dan online shop dalam pelaksanaan pelatihan dan pendampingan.

7. Tim Abdimasyarakat melaksanakan kegiatan yeng berkaitan dengan pengadaan barang, peralatan dan perlengkapan sebagai penunjang dalam proses kegiatan pelatihan dan pendampingan.

Tahapan pada pra kegiatan ini di lakukan selama satu bulan penuh sesuai dengan jadwal yang sudah ditentukan yaitu pada bulan februari 2021, dan dilanjutkan dengn tahap pelatihan dan pendampingan, lebih detailnya pada gambar 4 berikut rincian tahapan kegiatan pengabdian kepada masyarakat dibawah ini:

\begin{tabular}{|c|c|c|c|c|c|c|c|c|c|c|}
\hline \multirow{2}{*}{ No } & \multirow{2}{*}{ Kegiatan } & \multirow{2}{*}{ Tahap } & \multirow{2}{*}{$\frac{\text { Waktu }}{\text { (hari) }}$} & \multicolumn{4}{|c|}{ Feb-2021 } & \multicolumn{3}{|c|}{ Mart-2021 } \\
\hline & & & & 12 & 3 & 4 & 5 & 12 & 3 & 4 \\
\hline 1 & Membentuk Tim Abdimasyarakat & \multirow{9}{*}{ Pra Kegiatan } & 1 & & & & & & & \\
\hline 2 & Menyusun proposal kegiatan & & 2 & & & & & & & \\
\hline 3 & Tinjauan pustaka & & 3 & & & & & & & \\
\hline 4 & Survey lokasi perusahaan mitra & & 1 & & & & & & & \\
\hline 5 & Sosalisasi dengan perusahaan mitra & & 1 & & & & & & & \\
\hline 6 & Perizinan kegitan & & 1 & & & & & & & \\
\hline 7 & Pendaftaran calon audiens pelatihan & & 1 & & & & & & & \\
\hline 8 & Penyusunan modul pelatihan & & 4 & & & & & & & \\
\hline 9 & Pengadaan perlengkapan kegiatan & & 1 & & & & & & & \\
\hline 10 & Pelatihan pemasaran online & Pelatihan & 1 & & & & & & & \\
\hline 11 & Pembuatan akun marketplace & \multirow{2}{*}{ Pendampingan } & 1 & & & & & & & \\
\hline 12 & Pelaksanaaan pemasaran online & & 4 & & & & & & & \\
\hline 13 & Penyusunan Jurnal IImiah & \multirow{2}{*}{-Pasca Kegiatan } & 6 & & & & & & & \\
\hline 14 & Penyusunan laporan kegiatn & & 3 & & & & & & & \\
\hline & Total Waktu & & $\begin{array}{c}30 \\
\text { hari }\end{array}$ & & & & & & & \\
\hline
\end{tabular}

Gambar 4. Rincian Kegiatan Pengabdian Masyarakat

Tahap yang kedua, yaitu pelatihan, pelatiha online marketing di laksanakan di laboratorium komputer Fakultas Teknik pada hari Kamis 4 Maret 2021. jadwal pelatihan di mulai pada pukul 09.30 sampai dengan pukul 16.00 . Materi dan modul yang di berikan oleh pemateri atau tutor tentang online business dan online marketing menggunakan media marketplace. Tutor atau pemateri di pelatihan ini dilaksanakan oleh satu orang dosen serta di bantu 
oleh asisten tutor sebanyak tujuh orang mahasiswa. Peserta pelatihan diikuti sebanyak dua puluh orang mahasiswa yang tergabung dalam Himpunan Mahasiswa Teknik Informatika, Fakultas Teknik Universitas Nurul Jadid. Disaat pelatihan berjalan, peserta diberikan kesempatan untuk sesi tanya jawab atau diskusi dengan bebas. Berikut ini hasil dokumentasi pada acara pelatihan pada gambar 5 .

Tahapan yang ketiga yaitu pendampingan, dimana proses pendampingannya dengan materti pengenalan dan pembuatan akun marketplace yang dimulai berlangsung selama satu hari, yaitu pada hari Kamis, 4 Maret 2021, dimulai pada pukul 09.30 WIB dan berakhir pada pukul 16.00 WIB. Beda dengan pelatihan, pada sesi pendampingan ini yang hanya di ikuti oleh kelompok mahasiswa Himpunan Mahasiswa Teknik Informatika yang berstatus santri. Modul dan materi pada pendampingan ini ialah pembuatan dua akun marketplace yaitu Shopee.co.id dan Tokopedia.com yang di praktekkan langsung oleh mahasiswa yang di dampingi oleh tutor dan tujuh aisten tutor. Perlengkapan yang diperlukan yaitu DLP, laptop, Komputer dekstop tiap peserta, projector, dokumen profil perusahaan, akses internet, dan dokumen seperti gambar produk hasil karya pesantren yang akan di pasarkan ole perusahaan yang mana adalah NJ Mart.

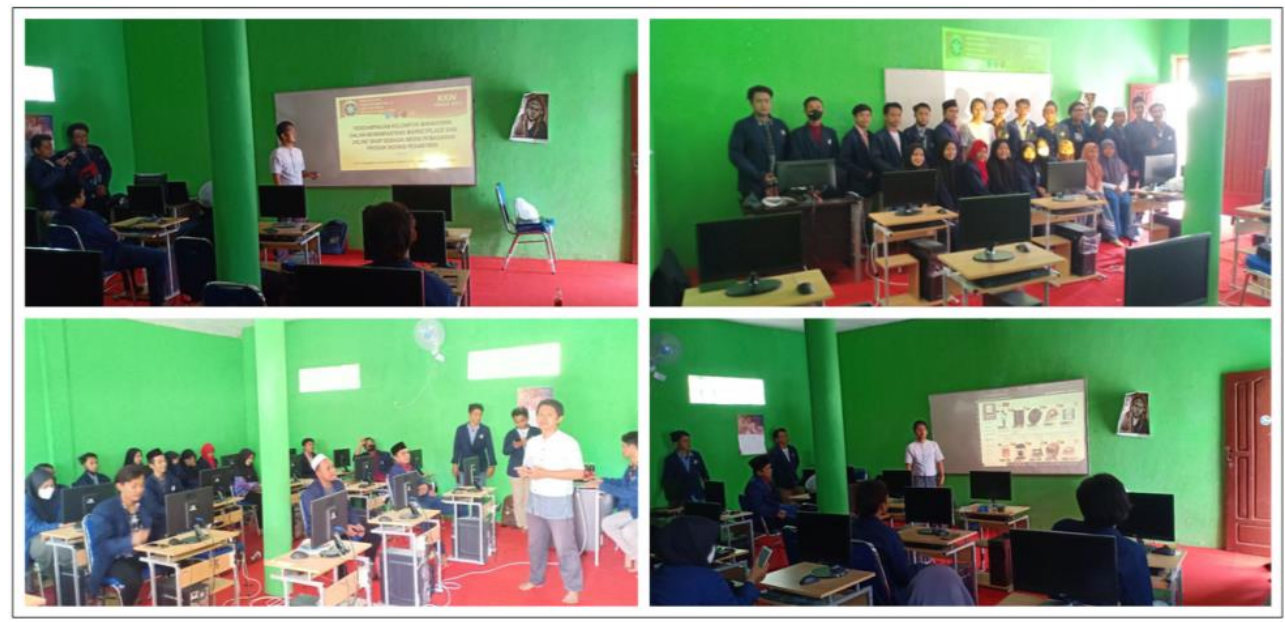

Gambar 5. Tutor menjelaskan materi pemanfaatan Marketplace dan Online Shop serta praktek pembuatan akun Marketplace dan Online Shop dipandu tutor dan pendamping

Membuat dan mengimplementasikan akun pemasaran online berbasis marketplace tidak harus membutuhkan waktu yang cukup lama, satu hari 
cukup. Akan tetapi dalam mengembangkan akun marketplace tersebut membutuhkan proses yang terus menerus selama bisnis di jalankan. Mahasiswa atau operator perlu meng update setiap ada produk baru dari pesantren yang akan di pasarkan, meng updatae harga - harga produk serta merubah informasi produk, menanggapi dan menjawab komentar dan pertanyann dari customer, memroses pesanan barang dari customer, memroses pembayaran produk, memberi konfirmasi pengiriman produk, sampai merespon dan menanggapi keluhan-keluhan dari customer. Maka dengan itu, pendampingan dilaksanakan oleh Tim Abdimasyarakat yang terdiri dari tutor ynag dibantu oleh asisten tutor selama satu bula penuh serta manfaat dalam memonitoring proses dalam pelaksanaan online marketing pada dua akun marketpalce. Setelah dilakukan pendampingan selama satu bulan penuh dari kejauhan secara online, di harapkan mahasiswa selaku audiens atau peserta bisa mandiri dalam pengembangan metode online marketing.

Berikut tahapan akhir dimana pasca kegiatan yang meliputi :

1. Publikasi Jurnal IImiah pada Jurnal IImiah GUYUB: Journal Of Community Engagement. Kegiatan Abdimasyarakat ini, menggunakan pendekatan ilmiah, dimana publikasi dijurnal ilmiah diharapkan bisa memperbanyak referensi ilmiah yang terkait dengan implementasi pengabdian masyarakat, online business, online marketing, dan marketplace.

2. Pelaksanaan kegiatan yang selanjutnya diakhiri dengan menyusunan laporan kegiatan dan disampaikan kepada pimpinan Universitas sebagai wujud akuntabilitas serta memenuhi salah satu beban kewajiban tridarma perguruan tinggi

Seluruh rangakaian pelatihan dan pendampingan dalam kegiatan pengabdian kepada masyarakat, didapat hasil tiga luaran, yang pertama meningkatkan keterampilan dan pemahaman mahasiswa, yang mana pengetahuan tentang online business dan kemampuan peserta tentang online marketing; yang ke dua, implementasi system akun marketplace Shopee.co.id dan Tokopedia.com yang di gunakan untuk media promosi serta memasarkan produk-produk yang di produksi dan dijual oleh NJ Mart selaku unit usaha; yang ke tiga, publikasi hasil kegiatan di jurnal ilmiah yang telah ditentukan. 
Pelatihan dan pendampingan yang di laksanakan memberikan ilmu pengetahuan tentang online bisnis, online marketing, dan online marketing berbasis marketplace. Sesi selanjutnya setelah proses pelatihan dilakukan pendampingan dalam membuat akun marketplace kemudian perusahaan bisa menerapkan online marketing. Sejalan dengan pendapat Mondy dalam bukunya (Mondy, 2008) menyatakan bahwasanya pelatihan di rancang untuk memberi keterampilan dan pengetahuan dan kemampuan baru di dapatkannya untuk aktivitas pekerjaan mereka setiap hari yaitu dengan cara pengembangan akun marketplace yang merupakan salah satu media promosi dan pemasaran produk yang di pasarkan perusahaan. Hal ini senada dengan yang di sampaikan Dessler (Dessler, 1997) bahwasanya pelatihan di tunjukkan supaya peserta pelatihan bisa mengimplementasikan pekerjaannya sendiri.

Proses pelatihan serta pendampingan yang di selenggarakan oleh Tim Abdimasyarakat menganut pada metode pelatihan dari Mondy (Mondy, 2008), yaitu :

1. Menetapkan kebutuhan-kebutuhan spesifik dari perusahaan yaitu dengan meningkatkan omset penjualannya. Dengan mengimplementasikan online marketing berbasis marketplace sehingga bisa menjaring customer yang sudah terbiasa berbekanja online aga supaya beralih dan belanja di akun toko marketplace yang nantinya berdampak pada meningkatnya omset penjualan perusahaan.

2. Menetapkan spesifik dari pendampingan yaitu dengan cara memberi keterampilan dan pengetahuan untuk dapat mengelola serta membuat akun pemasaran online Shopee.co.id dan Tokopedia.com.

3. Menentukan metode dan system penyampaian adalah satu hari untuk pelatihan dan satu bulan full untuk pendampingan. Dalam pelatihan yang berisi materi penyampaian yang berkenaan dengan hal umum untuk mencetuskan pengetahuan dan wwasan peserta, sedangkan untuk metode pendampingan satu-satu dengan system penyajian dimana tiap tutor untuk satu peserta dalam proses pendampingan pembuatan akun toko di marketplace.

4. Mewujudkan program, kegiatan yang utama yaitu pelatihan serta pendampingan. Pelatihan dilaksanakan dalam satu hari yang di pandu langsung oleh tutor dan asistennya. Mengenai proses pendampingan mengacu pada Desler (Dessler, 1997) ialah pendampingan dalam satu 
hari yang berbasis komputer. Dengan menggunakan pendekatan JIT (Job Instruction Training) tutor memberi tugas yang harus dilakukan oleh peserta untuk proses pembuatan akun marketplace sudah dibuat, selanjutnya proses pendampingan dilakukan dengan cara jarak jauh dengancara daring dalam satu bulan penuh, dimana tutor dan asisten tutor memonitor serta memberi masukan atas kemajuan akun marketplace yang sudah dibangun oleh peserta. Diman pelaksanaan dengan model seperti ini diterima oleh perusahaan mitra dan mahasiswa sebab efektif dalam hal waktu dan efisien dalam hal biaya.

5. Evaluasi kegiatan, dimana Tim Abdimasyarakat menetapkan duakali evaluasi kegiatan, yaitu setelah berakhirnya kegiatan ini untuk mengevaluasi kemajuan bisnis perusahaan mitra. Sebagaimana evaluasi di jadikan instrumen dalam mengukur pengaruh dari online marketing yang berbasis marketlace yang dijadikan acuan atas berubahnya pemasukan perusahaan. Proses evaluasi yang pertama dan kedua akan menjadi umpan balik dalam kegiatan-kegiatan pengabdian masyarakat yang selanjutnya.

Customer yang menggunakan marketplace bisa perorangan sebagai customer terakhir. Konteks dalam NJ Mart selaku unit usaha sebagai perusahaan mitra, bisa di katakan bahwasanya wilayah marketing NJ Mart melalui perantara marketplace yang berjenis business to consumer (B2C), dimana menjual secara online berupa barang dan jasa kepada customer terakhir dan business to business (B2B) dimana antara perusahaan ke perusahaan. Dengan pengaplikasian online marketing melalui marketplace di harapkan pemasukan penjualan NJ Mart lebih meningkat, dimana menjaring customer yang gemar berbelanja online.

\section{Kesimpulan}

Pelaksanaan kegiatan pengabdian kepada masyarakat dengan tema Pendmpingan kelompok Mahasiswa dalam Memanfaatkan Marketplace dan Online Shop sebagai media Pemasaran Produk Inovasi Pesantren berjalan dengan baik, tertib dan lancar sesuai dengan apa yang sudah direncanakan sebelum-sebelumnya. Kegiatan pendampingan ini mendapatkan sambutan yang sangat begitu antusias baik dari pihan NJ Mart dan Kelompok Himpunan Mahasiswa Teknik Informatika (HIMATIKA) Fakultas Teknik Universitas Nurul 
Jadid sebagai mitra selama dalam kegiatan pelatihan dan pendampingan berlangsung. Dari keseluruhan hasil saat pelaksanaan pelatihan dan pendampingan menunjukkan hasil yang positif dan menjadi peluang usaha serta meningkatkan minat mahasiswa dalam semangat berwirausaha.

\section{Pengakuan}

Alhamdulillah, puji serta syukur atas terlaksananya kegiatan pendampingan dalam pemanfaatan Marketplace dan Online Shop sebagai media pemasaran produk Pesantren. Tim Abdimasyarakat mengucapkan banyak terimakasih kepada NJ Mart selaku unit usaha pondok pesantren dan kelompok Himpunan Mahasiswa Teknik Informatika (HIMATIKA) Fakultas teknis Universitas Nurul Jadid selaku mitra yang telah memfasilitasi atas terlksananya pelatihan dan pendampingan ini. Tim abdimasyarakat juga mengucapkan banyak terimakasih kepada LP3M Universitas Nurul Jadid yang mana telah memberi amanah kepada tim kami untuk melaksanakan kegiatan pelatihan dan pendampingan ini baik secara material maupun non material.

\section{Daftar Pustaka}

Aditya, W. I., Aan , Y., Dwi , A., Reagan , D., \& dkk. (2020, Jli 2 - 25). Laporan Survei Internet APJII 2019 - 2020 [Q2]. Retrieved Februari 15, 2021, from https://apjii.or.id/survei

Creswell, J. W. (2016). pendekatan metode kualitatif, kuantitatif, dan campuran edise 5. Yogyakarta: Pustaka Belajar.

Dessler, G. (1997). Manajemen sumber daya manusia. Jakarta: Prinhalindo.

Dwi , H. J., \& Muhammad , A. R. (2020, September 21). Peta Persaingan ECommerce Indonesia pada Kuartal II-2020. Retrieved Februari 15, 2021, from Rata-Rata Kunjungan Web E-Commerce Bulanan (Kuartal II-2020):

https://databoks.katadata.co.id/datapublish/2020/09/21/petapersaingan-e-commerce-indonesia-pada-kuartal-ii-2020

Kotler, P., \& Gary , a. (2009). Prinsip-Prinsip Pemasaran edisi 12. Jakarta: Erlangga. 
Mondy, R. W. (2008). Human Resourse Management, Manajemen Sumber Daya Manusia, Jilid 1 Edisi 10. Alih Bahasa, Bayu Airlangga, MM. Jakarta: Erlangga.

Rahmad, S., Darmadi, Suhartono, A., \& Halomoan, K. Y. (2020). Pelatihan Online Business Karang Taruna Lingkungan Rw 013 Kelurahan Paninggilan Utara Kecamatan Ciledug Di Kota Tangerang. Abdi Abdi Laksana Jurnal Pengabdian Kepada Masyarakat, Volume 1 Nomor 2, Mei 2020, 161-165.

Sekretariat, N. (2021, Februari 15). Unit Pengembangan Usaha Pesantren Untuk Memfasiitasi Kebutuhan Santri dan Masyarakat. Retrieved Maret 21, 2020, from Pondok Pesantren Nurul Jadid - Paiton Probolinggo: https://www.nuruljadid.net/unit-usaha

Sugyono. (2010). Metode Penelitian Kuantitatif, Kualitatif, dan R\&D. Bandung: Alfabeta. 